\title{
TRANSLATION APPROACHES TO SECONDARY ANTHROPONYMIC NOMINATIONS (CASE STUDY OF B. OBAMA'S AND D. TRUMP'S NICKNAMING)
}

Yehorova O. I.

$\mathrm{PhD}$ in Philology; Associate Professor

ORCID ID 0000-0002-3225-5580

Sumy State University

2, Rymskyi-Korsakov St., Sumy, 40007, Ukraine

o.egorova@gf.sumdu.edu.ua

Turysheva 0.0 .

PhD in Philology; Associate Professor

ORCID ID 0000-0002-3168-5722

National Technical University of Ukraine "Igor Sikorsky Kyiv Polytechnic Institute", 37, Prosp. Peremohy, Kyiv, 03056, Ukraine

turysheva.kpi@gmail.com

Koval T. Yu.

Graduate student

Sumy State University

2, Rymskyi-Korsakov St., Sumy, 40007, Ukraine

tanya_koval96@hotmail.com

The study focuses on translating Barack Obama's and Donald Trump's secondary nominations. It suggests an inventory of techniques relevant to the translation of proper names and nicknames in particular. The analysis of open data on the Web exposed a limited number of cases of applying interlingual translation for rendering Barack Obama's and Donald Trump's nicknames despite the fact that the politicians have been assigned many during the terms of their office. Alongside, the analysis proved that the second life in other cultural spaces obtain only those bynames that had managed to gain the attention from the wider public, in particular, through a vast media coverage.

Among the most widely used methods of translating the politicians' nicknames, the techniques of transliteration, transcription, calquing, half-calquing, substitution, and descriptive translation prevail. The translator's goal is not only to apply the relevant translation strategy, but also to preserve the meaning and pragmatics of the original naming embedded by its author. Moreover, an adequate interlingual translation requires the translator to choose a method that would guarantee recognizability of the nickname regardless of the context. However, sometimes, traditional methods of translation lack sufficiency which requires turning to alternative approaches and triggering the translator's creative potential. In such cases, translator's virtuosity and linguo-creative skills would enable representing the fragments of the original (source) linguo-cultural space, preserving the implanted concept, as well as rendering both connotation and esthetic functions of the onyms in the target language. Thus, the article introduces the results of examining the existing translation solutions and provides with the authors' own solutions along with their grounding.

Keywords: proper name, anthroponomy, nickname, interlingual rendering, translation technique.

With each coming year, the problem of translating proper names puts on more weight

(C) Єгорова О. І., Туришева О. О., Коваль Т. Ю., 2019 
since the dynamics of intercultural communication in line with globalization and geopolitical processes produce a significant impact on all spheres of human activity. Overall liberalization and active international and intercultural interaction contribute to sharing new knowledge and spread of specific nominations beyond the bounds of a certain linguoculture or country. Thus, the importance of adequate intercultural mediation (translation) comes to the fore.

The relevance of the study is determined by the acceleration of global geopolitical processes and a salient rise of political consciousness within the US society in the last few decades. Moreover, the problems of translation of the informal names given to the supreme leaders lack sufficient coverage in the up-to-date translation studies, which objectifies the novelty of this study.

The subject matter of the research paper are informal personal names of the $44^{\text {th }}$ and $45^{\text {th }}$ US Presidents Barack Obama (362 items) and Donald Trump (409 items) obtained from the American blogosphere; the scope of the study covers peculiarities of their translation into Ukrainian.

The objective of the current research is an analysis of possible ways of translation of Barack Obama's and Donald Trump's nicknames. The tasks of the study are: 1) to draw up an inventory of relevant methods for translating nicknames; 2) to analyze the existing translation solutions of the Barack Obama's and Donald Trump's nicknames; 3) to suggest and argument adequate variants of translating nicknames.

The methods of study comprise traditional techniques of the inductive method, comparative, descriptive, and typological analysis.

Results of the research. Translation of proper names is to be compared with a titanic labor since it requires not only a profound schooling and intercultural competence, but also wide background knowledge and a particular flair for language, let alone creative skills. Proper names account for culture-specific words (realia) in any language. They designate particular person, place or object which characterizes culture of a nation [1, p. 103] and their wrong interpretation in other languages may cause misunderstanding at least, misconception at most.

Within the class of proper names, the subclass of anthroponymic units stands out against the rest. Here belong patronyms, surnames, family names, nicknames and pseudonyms (individual or group), as well as kryptonisms (a secret names) [2, p. 36]. All anthroponyms can be divided into primary ones, that is, official names (first and last names), and secondary ones, that is, informal names (nicknames, pseudonyms etc.).

Primary antroponyms mostly do not represent significant problems in the process of interlingual transmission; the translation of secondary onymic nominations requires specific translation skills and craft.

Translation is an activity carried out in a given cultural context, never in vacuo. Language-external factors and the communicative situation itself impose certain limits on the translator's freedom of choice. That limitation aside, there are pragmatic factors that dictate the strategies that can or must be followed when dealing with proper nouns in translation [3]. No doubts, there is no universal approach to rendering the name into another language since each particular case requires application of different strategies. Of great importance is to transfer the onym in such a way as to avoid unnaturalness in the target language and to preserve the semantics, emotiveness, and pragmatics borne by the original language unit.

S. Zabolotnaya neatly notices that most semantic divergences reveal at the level of connotation in case it is translated literally, and thus, deprived of the emotional components of meaning and those related to the background knowledge of the recipient of the original text [4] since a different linguocultural environment cannot meet the requirements of such correlation. Therefore, for the sake of preserving semantic content of a nickname in translation, a variety of translation strategies and techniques are to be applied.

Undoubtedly, in comparison with birth or legal names, most nicknames possess a particular "semantic charge" since they are charactonyms or telling names, i.e. they suggest certain distinctive traits of the character or mark a specific attitude towards their bearers. Therefore, the translator's task is to reproduce the content, emotional, expressive, and 
aesthetic value of the original to the fullest extent possible and to render the pragmatics of the source text by means of the target language.

The choice of translation variant is determined not only by the diversity of languages, heterogeneity of the socio-cultural environment, but also by the individuality of the translator. The latter is associated with his/her erudition and artistic perception, talent and idiolect (peculiar choice of language means) - all these factors influence the quality of translation [5, c. 10-11]. Therefore, in some cases translation may feature the elements of the translator's style that are undesirable but inevitable.

In modern translation studies, the problem of translating nicknames, in particular political ones, seems to be insufficiently covered. In our opinion, this is due to the fact that nicknames belong to the most dynamic layer of modern vocabulary whose expressiveness limits their functioning sphere. Political nicknames appear in the society as a kind of reaction to the actions and decisions made by the politicians, so they both quickly enter and leave the active vocabulary.

Over their presidency, both Barack Obama and Donald Trump had got a tremendously great number of nicknames - the fact speaking for a ceaseless rise of political activism in the USA. In most cases, popularity wins the nicknames given to a well-known person by another well-known person (politician, journalist, celebrity, etc.). In the case of politicians, such nicknames are primarily motivated by their political behavior or public activity, external appearance or character traits that become sources of jokes or caricaturing.

Unfortunately, the WWW provides the research, with little examples of ready-made traslations of nicknames, into Ukrainian in particular. Within the arranged sample of nicknames, some $95-98 \%$ are nonce words not widely used on a daily basis. Only the names that have drawn the public attention, in particular through their wide use media, have chances to survive and strike roots on the ground of a foreign linguoculture.

Among the existing translation solutions, the method of transliteration (approximate grapheme-to-grapheme conversion) was applied to rendering a number of Barack Obama's and Donald Trump's nicknames: Barry - Бappi, Barry O'Bomber - Бappi О'Бомбер (Barack Obama); Donald Duck - Дональд Дак (Donald Trump). In all these cases, the graphic form of the anthroponyms got approximated to that of the target language.

The method of transliteration demonstrates the same validity in translating into Ukrainian such nicknames as Bam-Bam-Бам-Бам, Bатту - Баммі, Bamster - Бамстер, Barky Баркі, Ватьі - Бамбі, Obатbi - Обамбі (Barack Obama); Dоnпіе TicТас-Донні ТікТак, Voldemort - Волдеморт (Donald Trump). Moreover, we suggest using the method when translating telescopic units such as: Маоьата - Маобама and ОьаМао - ОбаМао. The application of this translation technique does not cause any semantic losses, in particular when the nickname is derived from the primary nomination of the denotatum (proper name or surname of the nickname bearer) or is a product of onomatopoeia.

Transcription prevails in cases when transliteration threats to distort the sounding image of the nickname since alphabetic composition does not immediately correspond to the actual phonetic composition of the lexical unit: different letters may stand for one sound as well as different sounds may hide behind the same letters [6, p. 143]. When transcribing, the borrowing language very often imposes the pronunciation mode of the onym and adapts its form to its own standards and reading rules. E.g.: Bacrack Obата - Бакрак Обама, Baracka Claus - Барака Клаус (Barack Obama); Truтратіus - Tpannapiyc, Trumpinator Трампінатор, Scrooge McTruтр - Скрудж МакТрамп (Donald Trump).

Along with given proper names, fancy names get also transcribed. For example, the nickname of the acting president Donald Trump Trumpledore, a product of allusion to the literary character of a series of books about Harry Potter, can be translated by a soundingconserving analogue - Трамплдор (Donald Trump). The transmission of the acoustic image of the original word preserves the ethnocultural specifics of the nickname to the greatest extent possible.

Another popular translation solution when dealing with nicknames is the method of adaptive transcoding used in the cases of O-cialist - O-цianicm (Barack Obama); 
Adolf Twitler-Адольф Твітлер, Donald Dodo - Дональд Додо (Donald Trump). The method consists in adjusting the source lexeme to the spelling and pronunciation norms of the target language. Therefore, takes place the process of naturalization which is intended to facilitate the perception and comprehension of the nickname by the target recipient.

One of the specific translation solutions for interlingual transfer of the US presidents' nicknames is calquing or loan translation. Within the organized sample, there is only one case of application of this technique (Lame duck - Кульгава качка). However, in our opinion, the method of calquing is relevant when applied to a set of other nicknames from the sample. E.g. Chairman Zero - Президент Нуль, King Zero - Король Нуль, Odraта Одрама, Big Brother - Великий Брат, Celebrity of the United States - Зірка Сполучених Wmami, Jug-Eared Demigodlet - Клаповухий Напівбожок (Barack Obama); Agent Orange - Aгент Pудий, Boiled Ham in a Wig - Варена шинка в перуиі, Barbarian at the Debate - Варвар на дебатах (Donald Trump). In these cases, calquing not only it does not violate the rules of lexico-semantic and syntactic compatibility in Ukrainian, it "preserves" the semantic and pragmatic message embedded by the creators of these nicknames.

Unlike transcription, calquing is not a mere mechanical transfer of the original form of the word from one language into another. It often requires the use of certain transformations. This primarily relates to changes of case forms, the number of words in a phrase, affixes, word order, morphological, and syntactic status of words, etc. [7, p. 79]. Moreover, in some cases permutation occurs [8, p. 174], as in following cases: Dr. DoNothing-Доктор Нероба (Barack Obama), Liberals' Best Friend - Найкращчий Друг Лібералів (Donald Trump).

When the nickname takes the form of hybrid combination, which constitute a part legal name and additional notional lexemes ("telling" lexemes), the nickname is translated by means of half-calquing. This way of translation is used for rendering into Ukrainian Barack Obama's nickname No Drama Obата -Обама-без-драми. The translator both transliterates the surname of the president and changes the order of the components within the nomination (technique known as permutation). Another interesting case is the translation of the nickname The Donald - Той самий Дональд. In this situation, the translator takes the advantage of combining translation techniques of half-calquing and addition adjustment to reproduce not only particularizing function of the definite article, but also to render its augmentative function.

Half-calquing as a translation technique can be successfully applied when translating the nickname Barack Barack Obabykiller - Барак Одітовбивия into Ukrainian. Here, the target nickname not only preserves the original order of the constituents (Обама + дитина + вбивця), but also does not lose in expressiveness and stylisticy coloring. By analogy, we suggest translating the following set of nicknames: Fraudbama - Обмана («Обама» + «обманщик»), Obummer - Облама («Обама» + «обламатися»), Barack Ovomit - Барак Облювама («Обама + блювати»); Putin's Pet - Любимчик Путіна, Crybaby Trump Плакса Трамп. In our opinion, these translation variants sound quite natural in the Ukrainian translation and reproduce the connotative and pragmatic charge of the original nomination.

Another justified case of applying the combination of calquing and addition is the variant of translating Donald Trump's nickname Little Hands is into Russian as Дональд Трамп «Маленькие ручки». Tо avoid referential misunderstanding, the legal name of the nickname bearer is added. Since the Ukrainian and Russian languages are genealogically related, by analogy, the Ukrainian translation would look like Дональд Трамп «Маленькі ручки». In the similar case with the Russian translation of Barack Obama's nickname Jug Ears - Барак Лопоухий (Ukrainian - Барак Клаповухий), addition adjustment guarantees cognitive relating of the onym to its referent in the minds of the translation recipients, and thus, eliminates the need of appealing to a broader context or special background knowledge.

One of the most effective approaches to cross-language rendering of nicknames is the use of variant correspondences, also called substitution. Being a set of dictionary correspondences in fact, variant correspondences are numerous and their choice is stipulated by each particular context. Translator's craft, thus, consist in the ability to suggest the most relevant and contextually (situationally) justified translation variant. 
In particular, the method of variant correspondence is applicable to the translation of Barack Obama's nickname The Spineless Wonder. According to the Oxford English Dictionary, spineless applies to a weak and purposeless person, whereas wonder refers to the feeling of surprise and admiration caused by something beautiful or unfamiliar [9]. On determining the semantic filling of the nickname components, we revise the available variants of correspondences suggested in the English-Ukrainian dictionary and find regular equivalents: spineless - «безхребетний» [10, p. 1379] and wonder - «здивування, подив» [10, p. 1682]. However, regular correspondences do not reproduce the connotation embedded in the semantics of the original nickname. So, we turn to revising all translations suggested and decide in favor of «безхарактерний» ("weak-willed"). Thus, we consider the translation of The Spineless Wonder as Безхарактерне чудо a product of selection of variant correspondences.

A similar algorithm of translating works in the case of the Donald Trump's nickname Orange Clown motivated by the color of the president's spray tanned skin as it looks from the TV screens, and the overall Trump's desire to attract people's attention. Direct regular correspondence of the component clown - клоун, however, does not completely satisfy the requirements set at the level of connotation. The relevant level of derogation, in our opinion, is achieved through the application of domestication technique which makes the target text conform to the target culture. Thus, instead of internationalism клоун we give preference to the "local" lexical unit блазень, and thus, obtain Orange Clown-Помаранчевий блазень.

In the cases of derivatives, the method of variant correspondence should be often considered with regard to the root words. So, when translating Barack Obama's nickname Nutless Wonder - Безголове чудо, the selection of the variant correspondence of the first component nutless was made with reference to the set of dictionary meanings of its root lexeme nut [10, c. 954], one of the secondary meanings of which is «голова, макітра» (,head").

Within this research, we failed to identify the ready-made examples of the descriptive translation used for conveying the presidents' nicknames. In our opinion, this is due to the fact that by this mean, it is extremely difficult to translate the nickname briefly and accurately. However, descriptive translation is traditionally used in tandem with transliteration or transcription as in POTUS - ПОТУС (Президент Сполучених Штатів Америки). In this case, the translator both transliterated the abbreviation and decoded its semantic filling without which the translation would be qualified as inadequate.

The translation of nicknames that are nonce words and the products of author's inventiveness is a special challenge since the dangers of form distortion or loss of connotation and expressiveness. The task of the translator consists in suggesting a nonce equivalent, i.e. their own semantic neologism. This method is to be applied when dealing with the author's occasionalisms in the source language if the aforementioned translation techniques turn out inefficient. This translation technique differs from calquing due to the lack of etymological connection between it and the original word [11, p. 514].

Unfortunately, so far, we found no examples of translation solutions of this kind. The reason for that might be the need of inspiration, inborn creativeness and talent, so the translators tend to apply one of the traditional methods of interlingual translation of onyms. As our own example, we suggest translating Donald Trump's nickname Trumpetoes (to trample - топтати; to tread on one's toes - зачіпати почуття, наступати на хвору мозоль) by means of nonce equivalent Розтрамптуватель for it preserves the semantics, the pragmatics, emotional coloring and, what is of special value, the wordplay Trump trample resulting in onomatopoeia.

We also consider rather creative and appropriate such translation variants as Donald TaxDuck - Дональд Податкокряк, Mr. Wiggy Piggy - Пан Свинячий Чубчик (Donald Trump); President Blame Things - Президент Моя-Хата-Скраю та Bystander-in-Chief- Зівака в законі (Barack Obama) since they produce the same emotional effect and neatly render the denotative meanings of the original names. 
Preserving the rhyme when producing nonce equivalents is, however, a tour de force. As an example, we suggest considering the translation of Barack Obama's nickname Whacky Barracky as Барак дурних справ мастак by means of lexico-semantic technique of modulation. This particular example witnesses the preservation of rhyming (plane of expression) and the semantics short-sightedness (plane of contents). Another translation variant Барачок Дурачок is also acceptable for it reproduces not only the rhyming scheme but also the lexico-morphemic peculiarities of the original (the diminutive English suffix $-y$ is an equivalent to the Ukrainian - $о \kappa)$. However, from the point of the meaning and emotive power, such translation variant seems somewhat primitive. Thus, while translating nicknames, the translator often has to balance between the desire to preserve the meaning of the nickname (both denotative and connotative) and to sacrifice the "wrapping", or to convey the external form of the name at the expense of the "internal" losses.

Conclusions. Our analysis of the existing translation solutions found in the WWW has demonstrated that when dealing with nicknames the translators tend to use the conventional methods of translating proper names as the non-equivalent vocabulary in general: by means of transcoding and calquing. The methods of calquing and half-calquing - often accompanied by permutation - are usually used when translating "telling" nicknames which refer to certain characteristics of the denotatum. In the cases of polysemy, the method of substitution should be applied to choose the most contextually "suitable" variant from the set of dictionary translations. Adequate interlingual translation of nicknames requires thorough and grounded selection of the translation methods that would guarantee recognizability of the denotatum regardless of the context. However, sometimes traditional methods prove their insufficiency, so the translator should activate one's creative potential and reinvent the nickname (suggest nonce equivalent) that would preserve the connotations and expressiveness of the original.

\section{СПОСОБИ ПЕРЕКЛАДУ ВТОРИННИХ АНТРОПОНІМНИХ НОМІНАЦІЙ (НА МАТЕРІАЛІ ПРІЗВИСЬК Б. ОБАМИ ТА Д. ТРАМПА)}

\section{Сгорова O. I.}

Кандидат філологічних наук, доцент

ORCID ID 0000-0002-3225-5580

Сумський державний університет

вул. Римського-Корсакова, 2, м. Суми, 40007, Україна

philology_sumdu@ukr.net

Туришева О. 0.

Кандидат філологічних наук, доцент

ORCID ID 0000-0002-3168-5722

Національний технічний університет України «Київський політехнічний інститут імені Ігоря Сікорського»

проспект Перемоги, 37, м. Київ, 03056, Україна

turysheva.kpi@gmail.com

Коваль Т. Ю.

Студентка

Сумський державний університет

вул. Римського-Корсакова, 2, м. Суми, 40007, Україна

tanya_koval96@hotmail.com

У фокусі дослідження - переклад прізвиськ 44-го й 45-го президентів США Барака Обами та Дональда Трампа. У статті здійснюється інвентаризація прийомів, релевантних для перекладу власних назв $i$ прізвиськ зокрема. Аналіз відкритої інформації мережі Інтернет доводить обмеженість випадків інтерлінгвального перекладу прізвиськ Барака Обами та Дональда Трампа, хоча й за час президентства політиків присвоєння їм прізвиськ набуло масового характеру. Подальше життя на 
трунті інших лінгвокультур отримують лише ті прізвиська, які стали предметом уваги широкого загалу, зокрема через широке медійне висвітлення.

Серед найрозповсюдженіших методів перекладу прізвиськ політичних діячів найчастіше використовуваними прийомами міжмовної передачі є транслітерація, транскрипція, калькування, напівкалькування, лексична заміна та описовий переклад. При перекладі прізвиськ перед перекладачем постає завдання не лише обрати вірну стратегію, а й зберегти зміст та прагматику іменування, закладені у нього автором. Крім того здійснення адекватної міжмовної передачі оніму вимагає обирати такий перекладацький метод, який би зумовив упізнаваність нікнейму незалежно від контексту. Проте у випадках, коли традииійні способи перекладу не виявляють достатньої валідності, перекладач змушений звертатися до альтернативних методів та активізувати власний креативний потениіал. У таких випадках віртуозність та мовотворчі вміння перекладача сприятимуть відтворенню фрагментів оригінальної лінгвокультури в мові перекладу, а також збереженню закладених в іменування смислів, їхньої конотації та естетичних функцій. Таким чином, у пропонованому дослідженні аналізуються існуючі перекладаџькі рімення, а також пропонуються власні з обтрунтуванням їхньої валідності.

Ключові слова: власна назва, антропонім, прізвисько, інтерлінгвальна передача, метод перекладу.

\section{СПИСОК ВИКОРИСТАНИХ ДЖЕРЕЛ}

1. Seel O. I. Redefining Translation and Interpretation in Cultural Evolution / O. I. Seel. IGI Global, 2017. - 310 p.

2. Языкознание. Большой энциклопедический словарь [гл. ред. В. Н. Ярцева]. Москва : Большая Российская энциклопедия, 2000. - 688 с.

3. Särkkä H. Translation of Proper Names in Non-fiction Texts [Electronic resource] / H. Särkkä // Translation Journal. - Volume 11, №1. - 2007. - Access mode : https://translationjournal.net/journal/39proper.htm. - (30.09.2018).

4. Заболотная С. А. Ономастическая образность как проблема славянославянского художественного перевода [Электронный ресурс] // Jazyk a kultúra : Научный интернет журнал Центра исследования лингвокультурологии и переводоведения Философского факультета Прешовского университета в Прешове. - 2013. Режим доступа : http:/www.ff.unipo.sk/jak/16_2013/zabolotnaja.pdf. - (06.09.2018).

5. Королькова С. А. Особенности перевода жанра фэнтези: передача пространнствено-временных отношений (на материале романа «Артур и минипуты» Л. Бессона) // Homo Loquens : (Вопросы лингвистики и транслятологии) : сб.ст. - Вып. 6 / Федер. гос. бюдж. образоват. учреждение высш. проф. образования «Волгогр. гос. ун-т», Каф. теории и практики перевода. - Волгоград : Изд-во ВолГУ, 2013. - С. 9-19.

6. Кочерган М. П. Вступ до мовознавства / М. П. Кочерган. - К. : Академія, 2004. $368 \mathrm{c.}$

7. Телендій Р. О. Вирішення проблеми перекладу англійських топонімів українською мовою / Р. О. Телендій, Г. І. Сидорук // Zbiór raportów naukowych. "KNOWLEDGE SOCIETY". - Warszawa : Wydawca : Sp. z o.o. "Diamond trading tour", 2014. - C. 78-80.

8. Комиссаров В. Н. Теория перевода (лингвистические аспекты) : учебник для студентов институтов и факультетов иностранных языков / В. Н. Комиссаров. Репр. изд. - М. : Альянс, 2013. - 253 с.

9. Oxford Dictionaries [Electronic resource] / Oxford University Press, 2018. - Access mode : https://en.oxforddictionaries.com/. - (22.06.2018).

10. Англо-український словник / Гороть С. І., Коцюк Л. М., Малімон Л. К., Павлюк А. Б.; під заг. кер. С. І. Гороть. - Вінниця : Нова Книга, 2006. - 1700 с. 
11. Кузнєцова I. В. Переклад культурно-забарвленних слів / І. В. Кузнєцова // Наукові праці історичного факультету Запорізького державного університету. Запоріжжя : Просвіта, 2007. - Вип. XXI. - C. 513-516.

\section{REFERENCES}

1. Seel O.I. Redefining Translation and Interpretation in Cultural Evolution. IGI Global, 2017, 310 p.

2. Linguistics. Unabridged Encyclopedic Dictionary [ed. V. N. Yartseva]. Moscow: Unabridged Russian encyclopedia, 2000, 688 p.

3. Särkkä H. Translation of Proper Names in Non-fiction Texts [Electronic resource]. Access mode: https://translationjournal.net/journal/39proper.htm. - Accessed: 30.09.2018.

4. Zabolotnaya S. A. Onomastic figurativeness as a problem of Slavic-Slavic literary translation [Elektronnyi resurs]. Rezhim dostupa: http://www.ff.unipo.sk/jak/16_2013/zabolotnaja.pdf. - Accessed: 06.09.2018.

5. Korolkova S. A. Features of the translation of the fantasy genre: the rendering of spacetime relations (based on the novel "Arthur and the Miniputes" by L. Besson), Homo Loquens. Volgograd: Publishing House of VolSU, 2013, pp. 9-19.

6. Kochergan M. P. Introduction to linguistics. K.: Akademia, 2004, 368 p.

7. Telendiy R. O. Solving of the translation problem of English toponyms into Ukrainian, Zbiór raportów naukowych. "KNOWLEDGE SOCIETY". Warszawa: Wydawca: Sp. z o.o. "Diamond trading tour", 2014, pp. 78-80.

8. Komissarov V. N. Theory of Translation (linguistic aspects): a textbook for students of institutes and departments of foreign languages. M.: Alians, 2013, 253 p.

9. Oxford Dictionaries, Oxford University Press, 2018. - Access mode : https://en.oxforddictionaries.com/. - Accessed: 22.06.2018.

10. Gorot E. I., Kotsyuk L. M., Malimon L. K., Pavlyuk A. B. English-Ukrainian dictionary. Vinnitsa: Nova Kniga, 2006, 1700 p.

11. Kuznetsova I. V. Translation of cultural-colored words, Scientific works of the historical faculty of Zaporizhzhya State University. Zaporizhzhya: Prosvita, 2007, №21, pp. 513-516.

Received: 26 December, 2018 